\title{
Strategi Pemasaran Desa Ubud sebagai Destinasi MICE
}

\author{
IGPB Sasrawan Mananda1 ${ }^{1}$, Luh Gede Leli Kusuma Dewi ${ }^{2}$ \\ Fakultas Pariwisata, Universitas Udayana \\ email: gusmananda@unud.ac.id ${ }^{1}$, lelikusumadewi@gmail.com²
}

\begin{abstract}
The concept of mass tourism has two seasons namely high season and low season to determine the number of tourist visits each year. Therefore the tourism industry tries to conduct a vigorous promotion by carrying out activities that can bring tourists to stay in one tourist destination. One of the activities that entrepreneurs do in the low season is to conduct activities called MICE (Meetings, Incentives, Conventions, and Exhibitions). This research uses qualitative analysis technique by applying the participatory principle involving MICE stakeholders, destination manager, travel agent managers, and tourists. Ubud Village as a tourist destination which has potential for MICE activities has not had a convention bureau. This is due to the characteristics of the tourists who come to Ubud and the needs required by the tourism industry managers which are different from other tourist destinations in Bali such as Badung regency and Denpasar municipality. During this time, the implementation of activities of MICE is dominated by incentives tourism activities (56.57\%), exhibitions (31.72\%), and meetings $(11.71 \%)$. The SWOT results concluded that Ubud Village is still $S>W$ and $O \geq T$ thus requiring an internal consolidation, but seeing $\mathrm{O} \geq \mathrm{T}$, has potential for further development. Development strategy were using grand strategy which make the results such as growth, dominance, and maximum investment.
\end{abstract}

Keywords: MICE, marketing strategy, SWOT.

\section{PENDAHULUAN}

Konsep wisata masal memiliki dua musim yaitu musim ramai (high season) dan musim sepi (low season) yang menentukan jumlah kunjungan wisatawan setiap tahunnya. Terdapat dua musim ramai (high season) yaitu pada bulan dengan rentang Juli-Agustus dan desember-januari sedangkan bulan lainnya merupakan musim sepi (low season), hal ini menyebabkan pihak industri pariwisata berusaha untuk melakukan promosi yang gencar dan 
aktivitas-aktivitas yang dapat mendatangkan wisatawan untuk menginap atau menikmati destinasi wisata pada musim tersebut, salah satu kegiatan yang pengusaha lakukan pada musim sepi (low season) adalah dengan melakukan kegiatan MICE (meetings, incentives, conventions, and exhibitions) yang sangat berguna untuk mendatangkan jumlah wisatawan yang kontinu ke Indonesia pada umumnya dan Bali pada khususnya.

Dari sisi perkembangan dalam menangani kegiatan konvensi, Bali dapat dikatakan mampu bersaing untuk merebut peluang dalam penyelenggaraan konvensi. Pada tahun 2015 hampir sebagian dari total kegiatan MICE seluruh Indonesia dilaksanakan di Bali. Sejumlah 118 kegiatan yang ada di diselenggarakan di Bali, akan tetapi terjadi peningkatan pada tahun 2013 dan 2014. Perkembangan kegiatan usaha jasa MICE yang dilakukan oleh pihak hotel ditunjukkan oleh Tabel 1 berikut.

Tabel 1. Jumlah Penyelenggaraan Konvensi Nasional dan Internasional di Bali Tahun 2013-2015 (kali)

\begin{tabular}{|c|c|c|c|c|c|c|}
\hline \multirow{2}{*}{ Fasilitas Konvensi } & \multicolumn{6}{|c|}{ Tahun } \\
\hline & 2013 & $+/-\%$ & 2014 & $+/-\%$ & 2015 & $+/-\%$ \\
\hline Jenis Konvensi ( $\mathrm{KL}$ ) & 83 & $(34,65)$ & 106 & 27,71 & 118 & 11,32 \\
\hline A. Nasional & 7 & $(69,57)$ & 32 & 357,14 & 33 & 3,13 \\
\hline B. Internasional & 76 & $(26,92)$ & 74 & $(2,63)$ & 85 & 14,86 \\
\hline Jumlah Peserta (Orng) & 10,000 & $(50,00)$ & 75,333 & 653.33 & 10,000 & $(86,73)$ \\
\hline Uraian Kegiatan $(\mathrm{KL})$ & 83 & $(34,65)$ & 106 & 27,71 & 118 & 11,32 \\
\hline A. Meeting & 45 & $(40,00)$ & 33 & $(26,67)$ & 79 & 139,39 \\
\hline B. Incentive & 2 & & 8 & 300,00 & 1 & $(87,50)$ \\
\hline C. Convention & 30 & $(40,00)$ & 44 & 46,67 & 35 & $(20,45)$ \\
\hline D. Exhibition & 6 & 200,00 & 21 & 250,00 & 3 & $(85,71)$ \\
\hline
\end{tabular}

Sumber: Diparda Propinsi Bali (2016)

Sementara untuk pengumpulan data perkembangan kegiatan pelaksanaan usaha jasa konvensi, dari sekian banyak hotel di Bali, rata-rata 
hanya 15 hotel yang rajin melaporkan kegiatan konvensinya. Jumlah wisatawan mancanegara dan nusantara dengan tujuan MICE dapat dilihat di bawah ini.

Tabel 2. Jumlah Wisatawan Mancanegara dan Nusantara ke Bali Tahun 2008-2015

\begin{tabular}{|cccccccccc}
\hline \multirow{2}{*}{ Tahun } & \multicolumn{2}{c}{ Persentase } & \multicolumn{2}{c}{$\begin{array}{c}\text { Kedatangan Wisatawan } \\
\text { Ke Bali }\end{array}$} & \multicolumn{2}{c}{$\begin{array}{c}\text { Wisatawan dengan } \\
\text { Tujuan MICE }\end{array}$} & Total & + +/-\% \\
& & Wisman & Wisnus & Wisman & Wisnus & Wisman & Wisnus & & \\
\hline 2008 & $3,63 \%$ & $4,00 \%$ & 1.968 .892 & 2.898 .794 & 71.471 & 115.952 & 187.423 & - \\
\hline 2009 & $3,63 \%$ & $1,30 \%$ & 2.229 .945 & 3.521 .135 & 80.947 & 45.775 & 126.722 & $(32,39)$ \\
\hline 2010 & $1,91 \%$ & $4,10 \%$ & 2.493 .058 & 4.646 .343 & 47.617 & 190.500 & 238.117 & 87,91 \\
\hline 2011 & $3,25 \%$ & $1,00 \%$ & 2.756 .579 & 5.675 .121 & 89.589 & 56.751 & 146.340 & $(38,54)$ \\
\hline 2012 & $2,10 \%$ & $5,20 \%$ & 2.892 .019 & 6.063 .558 & 60.732 & 315.305 & 376.037 & 156,96 \\
\hline 2013 & $3,55 \%$ & $3,60 \%$ & 3.278 .598 & 6.979 .535 & 116.390 & 251.263 & 367.653 & $(2,23)$ \\
\hline 2014 & $4,36 \%$ & $7,20 \%$ & 3.766 .638 & 6.392 .461 & 164.225 & 460.257 & 624.483 & 69,86 \\
\hline 2015 & $4,36 \%$ & $2,40 \%$ & 4.001 .835 & 7.147 .100 & 174.480 & 171.530 & 346.010 & $(44,59)$ \\
\hline SUmb
\end{tabular}

Sumber: Dinas Pariwisata Provinsi Bali 2016

Berdasarkan Perda Provinsi Bali No 2 tahun 2012 menyatakan bahwa pemasaran dari pariwisata di Bali sesuai dengan konsep dari Pariwisata Budaya, sehingga budaya Bali perlu dijaga sehingga tetap terjaga dan berkelanjutan. Salah satu daerah tujuan wisata yang tetap menjaga budayanya adalah Desa Ubud yang masih memertahankan budaya Bali masih kental dan juga sebagai desa internasional yang mampu menarik wisatawan untuk datang berkunjung ke Ubud. Desa Ubud terbagai atas 8 desa antara lain: Desa Kedewatan, Desa Lodtunduh, Desa Mas, Desa Peliatan, Desa Petulu, Desa Sayan, Desa Singakerta dan Kelurahan Ubud.

Berdasarkan latar belakang tersebut di atas, yang menjadi tujuan khusus dari penelitian ini adalah:

1. Mengidentifikasi elemen-elemen produk wisata MICE di Desa Ubud.

2. Mengidentifikasi produk Destinasi MICE berdasarkan aspek bauran pemasaran

3. Merancang strategi pemasaran produk Destinasi MICE di Desa Ubud. 
TINJAUAN PUSTAKA

Wisata MICE

Destinasi MICE adalah Wisata Konvensi, Perjalanan Incentive dan Pameran dalam industri pariwisata. Apa yang dimaksud dengan MICE?

$\mathrm{M}=$ Meeting adalah istilah bahasa Inggris yang berarti Rapat, Pertemuan atau Persidangan adalah merupakan hal yang lazim bahwa rapat, pertemuan atau persidangan ini diselenggarakan oleh kelompok orang yang bergabung dalam suatu asosiasi, perkumpulan atau perserikatan.

I = Incentive, Istilah incentive, oleh pemerintah Indonesia seperti tercantum dalam UU No.9 tahun 1990 tentang kepariwisataan diartikan sebagai perjalanan Insentif. Selanjutnya perjalanan insentif ini ditentukan kegiatan usahanya yang merumuskan perjalanan insentif merupakan suatu kegiatan perjalanan yang diselenggarakan oleh suatu perusahaan untuk para karyawan dan mitra usaha sebagai imbalan penghargaan atas prestasi mereka dalam kaitan penyelenggaraan konvensi yang membahas perkembangan kegiatan perusahaan yang bersangkutan.

$\mathrm{C}=$ Conference, Istilah conference diterjemahkan dengan Konferensi dalam bahasa Indonesia yang mengandung pengertian yang sama, menyebutkan bahwa konferensi, kongres atau konvensi merupakan suatu kegiatan berupa pertemuan sekelompok orang (negarawan, usahawan, dan sebagainya) untuk membahas masalah-masalah yang berkaitan dengan kepentingan bersama.

$\mathrm{E}=$ Exhibition, Exhibition berarti pameran. Dalam kaitannya dengan industri pariwisata, pameran termasuk dalam bisnis wisata konvensi.

Tinjauan Tentang Strategi Pemasaran Jasa

Secara konsepsional Sucherly (2003: 219) menyatakan bahwa strategi pemasaran jasa mencakup dua strategi utama yaitu strategi pasar (market strategy) dan strategi bauran pemasaran (marketing mix strategy)

1. Strategi Pasar (market strategy)

Strategi pasar pada intinya menentukan segmen pasar yang akan dilayani (target market) dan pemposisian pasar (market positioning). 
Penentuan target market sangat penting mengingat tuntutan pelanggan tidak sama, sehingga kalau tuntutan berbeda maka cara melayaninya akan berbeda. Tujuan penting dalam pemilihan target market adalah mencari pasar yang paling berpeluang (tingkat persaingan yang relatif rendah). Dalam positioning, intinya adalah menempatkan marketing mix dengan tujuan untuk meraih keunggulan bersaing (competitive advantage) di target market (Sucherly, 2003: 219).

\section{Strategi Bauran Pemasaran (marketing mix strategy)}

Marketing mix pada dasarnya serangkaian variabel yang dapat dikendalikan perusahaan untuk memuaskan pasar sasaran dalam mencapai tujuan perusahaan (Brown, 1991: 23). Dalam pemasaran barang (tangible) dikenal empat alat yaitu: product, price, place and promotion atau The Four Ps. Keempat alat tersebut tersebut sebagai The Traditional Marketing Mix.

Menurut Kotler (2002: 18), bauran pemasaran (marketing mix) adalah seperangkat alat pemasaran yang digunakan perusahaan untuk terusmenerus mencapai tujuan pemasaran di pasar sasaran.

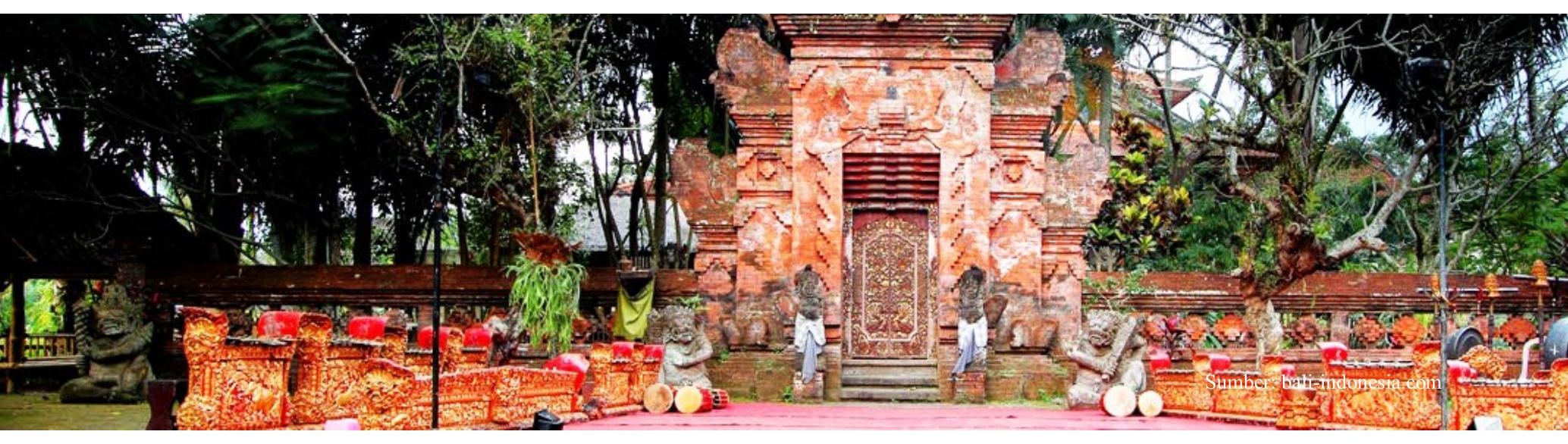

\section{HASIL DAN PEMBAHASAN}

Identifikasi Elemen-elemen Wisata MICE

Bali adalah salah satu destinasi MICE di Kawasan Asia Pacifik. Getz (1991: 45), dalam bukunya "Festivals, Special Event and Tourism", memberikan gambaran industri MICE dilihat dari sisi Supply. Getz menyatakan ada 7 (tujuh) elemen dalam sebuah destinasi MICE. Ada pun ketujuh elemen tersebut adalah 
(1) infrastruktur (infrastructure), (2) akomodasi (accomodation), (3) transportasi (transportation), (4) atraksi (attraction), (5) katering (catering), (6) pedagang pengecer (retail), (7) sarana rekreasi atau hiburan (recreation or entertainment). Gambar 1 oleh Getz, dapat diketahui kebutuhan apa yang perlu ditingkatkan dalam destinasi MICE.

Tujuh elemen destinasi MICE di Desa Ubud antara lain,

1. Infrastruktur

Sebagai salah satu destinasi wisata budaya, Desa Ubud memiliki kekayaan budaya yang harus terus dilestarikan akan tetapi Desa Ubud dihadapkan pada tantangan mengenai persoalan infrastruktur. Semakin terkenalnya Ubud di mata pariwisata global semakin banyak pula wisatawan yang berkunjung. Seiring dengan itu permintaan akan lokasi-lokasi penginapan dan hiburan juga terus bertambah di Ubud. Namun, Ubud adalah lokasi yang berbeda dan selalu menjunjung nilai-nilai adat dan budaya di mana tidak ada investor yang membangun klub dan hiburan malam di Ubud.

Masalah kemacetan juga menjadi salah satu hal yang digarisbawahi. Di mana jalan raya di Ubud tidak seluas jalan-jalan lain di Bali. Hal ini ditambah dengan semakin banyak wisatawan yang membawa kendaraan pribadi bahkan bus sehingga dibutuhkan penataan agar Ubud tidak ditinggalkan oleh wisatawan.

Minimnya kantong parkir dan penggunaan badan jalan sebagai tempat parkir serta rambu-rambu yang kurang terlihat jelas di jalur pedestrian yang tidak ramah dengan pejalan kaki. Ketiga hal tersebut menjadi faktor utama sebagai akar permasalahan yang terjadi di Ubud. Solusi mengatasi masalah kemacetan lalu lintas yakni menyediakan tempat parkir yang memadai, menjamin kenyaman dan keamanan pergerakan pengunjung ke lokasi-lokasi destinasi wisata tersebut.

Selain itu menyediakan jalur-jalur sepeda, dan pejalan kaki yang aman serta nyaman sebagai alternatif sistem transportasi dalam kawasan sekaligus menerapkan sistem informasi transportasi cerdas terpadu dalam pengendalian volume pergerakan, dan perparkiran, hal yang tidak kalah penting lainnya membangun sistem pengelolaan parkir berbasis Komunitas penyediaan sistem 
angkutan umum berbasis "Shuttle Service" yang melayani pengunjung menuju pergerakan ke pusat-pusat utama.

\section{Akomodasi}

Gianyar merupakan salah satu tujuan wisata di pulau Bali memiliki 390 buah tempat akomodasi, dengan rincian 19 buah hotel bintang dan 367 hotel nonbintang. Dari 390 buah hotel tersebut, terdapat hotel dengan jumlah kamar $>$ 25, memiliki 2.042 buah kamar dengan jumlah tempat tidur sebanyak 2.624 tempat tidur. Pada tahun 2016 rata-rata lama menginap pada hotel bintang selama 2,76 hari dan hotel nonbintang selama 4,05 hari.

Tingkat hunian kamar hotel pada tahun 2015 di Kabupaten Gianyar adalah $57,22 \%$ untuk hotel berbintang, dan 36,96\% untuk hotel nonbintang. Secara keselururuhan tingkat hunian hotel di Gianyar adalah 47,09\%. Tingkat hunian kamar hotel tahun 2016 meningkat bila dibandingkan dengan tahun 2015 sebesar $44,67 \%$ untuk seluruh jenis hotel.

Merebaknya pembangunan hotel di wilayah Gianyar terutama di Ubud, disebabkan lokasinya berada di desa yang suasana alamnya masih asri dan alami. Hal itu juga didukung oleh adat-istiadat dan budaya yang melekat kuat pada kehidupan penduduknya. Faktor lain yang sangat berpengaruh adalah panorama alam Ubud yang mempesona, sawah berteras, dan lingkungan alam yang terpadu sehingga dapat memberikan suasana yang tenang dengan udara pedesaan yang sejuk dan segar. Pembangunan hotel yang memadukan gaya modern dan tradisional Gianyar Bali dan didukung oleh sanggar-sanggar seni, artshop, dan tempat-tempat pertunjukan seni tari turut memberikan warna tersendiri. Sanggar-sanggar seni yang ada maupun artshop menyediakan berbagai macam jenis seni kerajinan kayu seperti Barong dan Garuda yang merupakan replika dari benda-benda sakral. Demikian juga benda-benda seni kerajinan kayu yang lain seperti replika dari flora dan fauna yang dibentuk berdasarkan desain yang sedang berkembang.

Terdapat 32 hotel yang melakukan kegiatan MICE di Desa Ubud antara lain di mana Royal Pita Maha Resort and Spa memiliki 5 tempat pertemuan, Sthala Ubud (3 tempat pertemuan), Five Elemens, Sens, Plataran, Arma dan Taman 
Harum dan Ananda Cottage (2 tempat pertemuan) selanjutnya 1 tempat pertemuan untuk hotel Rijasa, The Ubud Village, Bali Spirit, Kamandalu, Wapa di Ume Resort, Komaneka at Bisma, Maya Ubud Resort, The Viceroy, Four Season, COMO Uma, Natura Villa Ubud, Amandari, Aniniraka, The Chedi, Furama Villa, Komaneka at Tanggayuda, The Payogan Villa, Pertiwi Resort, Puri Garden, Puri Saron, Puri Wulandari, Suly Resort, Tiing Gading Bungalows dan The Mansion Resort and Spa.

\section{Transportasi}

Luas Ubud adalah: 42,38 km², Ubud terletak di antara ketinggian 75-325 $\mathrm{m}$ di atas laut dan Panjang Jalan di Ubud pada tahun 2016, yaitu sepanjang $515.240 \mathrm{~km}$. Jalan sepanjang itu apabila dirinci menurut jenis permukaannya maka terdapat 515.240 jalan yang diaspal. Apabila jalan tersebut dirinci menurut kondisinya, maka sepanjang 283.895 km dengan kondisi baik, 144.051 km dengan kondisi sedang, sepanjang 61.851 km kondisinya rusak, dan 25.443 $\mathrm{km}$ dengan kondisi rusak berat.

Banyaknya kendaraan wajib uji pada tahun 2016 di Kabupaten Gianyar adalah 11.991 kendaraan, menurun bila dibandingkan dengan tahun 2016 sebanyak 12.710 buah kendaraan. Jumlah angkutan mobil barang pada tahun 2016 adalah 11.663 kendaraan, menurun bila dibandingkan dengan jumlah pada tahun 2015 yang jumlahnya 12.397 kendaraan. Terjadi penurunan sekitar 5,92\% pada tahun 2016. Dengan jumlah angkutan wisata yang mencapai 2565 buah, merupakan sebuah jumlah yang besar bagi penyediaan transportasi wisata MICE di Desa Ubud yang dapat dilihat pada Tabel 3 berikut.

Tabel 3. Jumlah Angkutan transportasi wisata di Desa Ubud

Tahun 2012 - 2016

\begin{tabular}{|cc|}
\hline Tahun & Jumlah Transportasi Wisata \\
\hline 2016 & 2.565 \\
2015 & 2.621 \\
2014 & 2.486 \\
2013 & 1.399 \\
\hline 2012 & 955 \\
\hline
\end{tabular}

Sumber: BPS Gianyar. 
4. Atraksi

Atraksi Wisata Alam antara lain: Mandala Wisata Wanara Wana, Bukit Campuhan Ubud, Atraksi Wisata Budaya antara lain: Nyuh Kuning Village, Pura Taman Saraswati Ubud, Tari Barong Ubud dengan lokasi antara lain Sandi Swara Wantilan, Puri Saren Ubud, Pura Dalem Ubud, Tari Legong Mahabrata Ubud, Tempat Pertunjukan Tari Legong di Ubud Bali, Puri Saren Ubud dan Puri Agung Peliatan dan Atraksi Wisata Buatan antara lain Agung Rai Museum Of Art (ARMA), Museum Neka Ubud, Museum Puri Lukisan Ubud, Museum Blanco Renaissance, Museum dan Galeri Seni Rudana, Kursus Memasak di Ubud, Pasar Seni Ubud.

\section{Katering}

Situs TripAdvisor tahun 2016 mencatat terdapat 516 restoran yang terdapat di kawasan Ubud. Jumlah ini belum termasuk rumah makan kecil dan menengah yang tidak tercatat dalam situs tersebut. Di tengah ketatnya persaingan dan semakin menjamurnya restoran nonlokal, masakan lokal dengan ciri khas Bali sangat mudah untuk ditemui di Masakan khas Bali di Ubud terbukti memberikan pengalaman budaya yang otentik bagi wisatawan domestik maupun mancanegara. Ini menunjukkan bahwa pemasaran wisata kuliner di sebuah destinasi wisata dapat menghasilkan manfaat bagi masyarakat lokal dan wisatawan Terdapat beberapa makanan yang sehat dan vegetarian antara lain Sari Organik, Café Pomengrate, The Kafe dan Bali Buda. Dengan banyaknya restoran di Desa Ubud membuat pecinta makanan membentuk suatu event yang diberi nama Ubud Food Festival. Ubud Food Festival (UFF) di tahun 2015 lalu berhasil membawa 6.500 pecinta kuliner dari Indonesia dan negara-negara lainnya untuk berkumpul merayakan kemeriahan dan kekayaan kuliner Indonesia yang berlangsung selama tiga hari dan diisi dengan program-program seperti demo memasak, workshops dan masterclass.

6. Retail

Pasar tradisional, adalah tempat transaksi barang atau jasa antara penjual dan pembeli, yang memiliki ciri-ciri sebagai berikut. a. memerjualbelikan 
barang/jasa kebutuhan sehari-hari secara eceran b. melibatkan banyak pedagang eceran berskala kecil c. Bangunan dan fasilitas pasarnya relatif sederhana d. Pemilikan dan pengelolaannya umumnya oleh pemerintah daerah, di Pasar Ubud terdapat 214 pedagang yang terdiri dari 5 pedagang emas.

\section{Rekreasi dan Hiburan}

Wisata Rafting di Sungai Ayung Ubud, Trekking Authentic Bali, Kursus Pembuatan Perak, Pub dan Bar, lapangan sepak bola dipusat Desa Ubud. Berdasarkan dari identifikasi elemen-elemen di atas, terdapat beberapa paket wisata yang dibuat oleh travel agent seperti Pacto Convex dan Pacific World terutama untuk program incentives di Desa Ubud antara lain Bali "Cooking Class \& Ubud Shopping, Bali Rise \& Shine in Bali" dan Bali "Ubud Arts \& Treasures", program dari DMC Asia Plus antara lain White Water Rafting, Eat and Pray Film location dan bergaya seperti Julia Robert dan blessing ceremony disalah satu pura di Desa Ubud, Monkey Forest, Dinner dengan Raja Ubud di Puri Saren dan pembuatan perak.

\section{Mengidentifikasi produk Destinasi MICE berdasarkan aspek bauran} pemasaran (4P)

Konsep pemasaran melihat situasi pasar yang menyangkut:

a). Product, produk dan jasa ditawarkan harus jelas dan bisa dinikmati sebagi produk dan jasa yang diunggulkan. Monkey Forest, Puri Ubud, tempattempat religi (Pura Gunung Lebah, Tirta Empul dan Sebatu), tempat hiburan, tempat atraksi, tempat rekreasi dan lain lain. Demikian pula jasajasa wisata seperti spa, rafting, melukis, membuat batik dan hiburan yang lain.

Desa Ubud sebagai destinasi MICE belum mempunyai sebuah convention bureau, hal ini disebabkan oleh karakteristik dari wisatawan yang datang ke Ubud dan kebutuhan yang diperlukan oleh pelaku industri pariwisata berbeda dengan daerah tujuan wisata lainnya di Bali seperti Kabupaten Badung dan Kotamadya Denpasar. Selama ini, kegiatan pelaksanaan MICE 
didominasi oleh kegiatan wisata Intensif $(56,57 \%)$, exhibition $(31,72 \%)$ dan Meeting $(11,71 \%)$. Jumlah wisatawan mancanegara dan domestik yang melakukan kegiatan wisata ke Desa Ubud dapat dilihat pada tabel sebagai berikut.

Tabel 4. Jumlah Wisatawan yang melakukan Destinasi MICE ke Desa Ubud Tahun 2012 - 2016

\begin{tabular}{lrrrrrrrr}
\hline \multirow{2}{*}{ Tahun } & \multicolumn{2}{c}{$\begin{array}{c}\text { Wisatawan } \\
\text { l orang }\end{array}$} & Total & \multicolumn{3}{c}{ Jumlah Wisatawan MICE / orang } \\
& $\begin{array}{l}\text { Manca } \\
\text { negara }\end{array}$ & Domestik & & & Meeting & Insentif & Convention & Exhibition \\
& & & & & & & \\
2012 & 22,771 & 30,981 & 53,751 & 6,294 & 30,407 & 0 & 17,050 \\
2013 & 38,096 & 21,085 & 59,180 & 6,930 & 33,478 & 0 & 18,772 \\
2014 & 54,685 & 48,065 & 102,750 & 12,032 & 58,126 & 0 & 32,592 \\
2015 & 55,748 & 15,338 & 71,086 & 8,324 & 40,213 & 0 & 22,548 \\
2016 & 102,015 & 28,851 & 130,865 & 15,324 & 74,031 & 0 & 41,510 \\
\hline
\end{tabular}

Sumber: Hasil Penelitian 2017

Kegiatan Insentif, mayoritas dilakukan oleh perusahaan swasta atau korporasi (corporate), dan selanjutnya kegiatan exhibition dilakukan oleh privat dengan dominan pengusung yaitu painting dan terdapat beberapa exhibition tentang Fotografi di mana pelukis yang akan melakukan ekshibisi akan bekerja sama dengan pemilik galeri, museum, hotel dan restoran agar mereka dapat memajang hasil karyanya dalam bentuk ekshibisi. Kegiatan Wisata MICE yang bertumpu pada Insentif dan exhibition terhadap kegiatan budaya yaitu atraksi wisata budaya dan pameran tentang lukisan menyebabkan destinasi Desa Ubud sebagai destinasi MICE di Bali.

Untuk kegiatan meeting (pertemuan) lebih didominasi oleh pertemuan yang diadakan oleh korporasi atau perusahaan-perusahaan yang melakukan kegiatan Destinasi MICE yang dikombinasikan dengan kegiatan insentif selama mereka tinggal di Desa Ubud.

b). Place; tempat-tempat yang dituju berurutan dan nyaman, rasa aman bagi para wisatawan dalam mendatangi daya tarik wisata. 
c). Price; harga yang ditawarkan adalah harga standard tidak perlu dengan cara "tawar menawar" sehingga turis asing tidak merasa di bohongi atau diperlakukan secara tidak layak, sehingga merasa puas.

d). Promotion; jauh jauh hari perlu di sosialisasikan dan dipromosikan melalui berbagai agen atau saluran distribusi (communication channels) seperti newspapers; personal selling; direct mail; flyers; radio; individual referral; television; e-mail; telephone; internet; posters dan lain-lain.

3. Merancang strategi pemasaran produk Destinasi MICE di Desa Ubud.

Desa Ubud sebagai destinasi MICE memerlukan perancangan strategi pemasaran sebagai destinasi MICE melalui analisis penilaian internal dan eksternal.

Analisis Penilaian Internal

1). Networking

Networking di Desa Ubud didominasi korporat sebesar 43\%, hal ini mengindikasikan bahwa kegiatan atau events yang diselenggarakan melibatkan pihak perusahaan yang melakukan kegiatan meetings dan insentif di Desa Ubud. Swasta memberikan kontribusi sebesar 33\% untuk networking terhadap perkembangan MICE, stakeholder dari luar negeri sebesar $12 \%$, pemerintah provinsi Bali sebesar 7\% dan pemerintah Kabupaten Gianyar sebesar 5\%. Tujuan networking meningkatkan penanaman modal, bisnis, meningkatkan produk unggulan daerah dan promosi terpadu. Berarti cocok dengan alasan Destinasi MICE, di Desa Ubud memiliki tingkat pertumbuhan yang tinggi, membuka lapangan pekerjaan bagi banyak orang, meningkatkan kesejahteraan rakyat serta memberi effect bagi masyarakat Desa Ubud.

\section{2) Manajemen}

Idealnya di dalam manajemen pariwisata fungsi perencanaan, pengorganisasian, pengarahan, pengendalian maupun evaluasi, namun masih banyak yang harus diperbaiki seperti pengarahan, pengendalian maupun evaluasinya. Untuk Desa Ubud, pengorganisasian berperan lebih besar yaitu 
$43 \%$, selanjutnya perencanaan merupakan kegiatan yang memegang peranan penting dalam manajemen pengelolaan MICE di Desa Ubud sebesar 34\%, selanjutnya pengarahan sebesar $15 \%$ dan pengendalian hanya $8 \%$, bahkan evaluasi belum pernah dilakukan, hal ini memerlihatkan bahwa apa yang direncanakan belum dapat direalisasikan, bahkan belum mendapatkan pengarahan dan pengendalian, serta evaluasi.

Alasan yang menyebabkan tidak efektifnya dalam pelaksanaan manajemen di Desa Ubud adalah dana yang terbatas dalam hal perencanaan dan koordinasi sebesar 45\%, infrastruktur 25\%, dukungan pemerintah 14\%, mengajak stakeholder eksternal $10 \%$ dan sumber daya manusia sebesar $5 \%$. Kondisi tersebut menunjukkan bahwa Desa Ubud perlu lebih intens mengundang stakeholder yang mampu menjadi investor khususnya event MICE, memerbaiki infrastruktur, dan melakukan kajian dengan mengundang para pakar dan akademisi untuk membenahi Desa Ubud sebagai destinasi MICE.

3) Promosi dan advertising yang efektif

Media promosi yang dilakukan melalui internet (web, blog, social media) sebesar $63 \%$, surat kabar sebesar $21 \%$ dan direct selling sebesar $16 \%$ yaitu pameran, baliho dan pariwisata budaya. Responden yang ditanya tentang media promosi dan advertising yang terbaik, tidak terdapat promosi dan advertising terbaik yang perlu dijaga menciptakan brand name, sehingga wisatawan teringat Desa Ubud. Desa Ubud dapat menjaring wisatawan asing secara efektif memanfaatkan Tourism Information Centre (TIC), tempat wisatawan mencari informasi daya tarik wisata dan layanan perjalanannya. TIC dihubungkan dengan web, elektronik mail, bahkan melalui majalah, bulletin, termasuk harian atau surat kabar, dan media televisi dan media lainnya, termasuk hotel-hotel di Ubud.

4) Kecepatan merespons pasar dan perubahan teknologi

Kecepatan merespon pasar dapat dilakukan melalui system online pada teknologi informasi ( $\mathrm{TI}$ ) dibidang pariwisata yang dikenal dengan e-tourism 
sebesar $42 \%$, selanjutnya melakukan kerjasama dengan investor sebesar 23\%, respon terhadap trend perkembangan Destinasi MICE yang memerlukan respon yang cepat agar dapat mengambil peluang untuk mendapatkan bisnis MICE sebesar 21\%, perbaikan infrastruktur dan perbaikan tempat wisata masing masing sebesar $11 \%$, lainnya sebesar $3 \%$ seperti membuat brand image serta brand name Desa Ubud. Padahal branding desa perlu dirumuskan untuk menciptakan kesan keunikan tersendiri.

5) Kerjasama perusahaan

Dalam mengembangkan Destinasi MICE perlu bekerja sama dengan perusahaan yang memberikan dukungan bagi Desa Ubud. Kerjasama yang dilakukan di dominasi pada saat terdapat events sebesar $45 \%$, kerjasama berkelanjutan sebesar 30\%, moment tertentu sebesar $14 \%$ dan membuat perencanaan untuk mengadakan events sebesar 11\%. Dalam melakukan kerjasama perlu adanya kegiatan yang saling menguntungkan $56 \%$, joint usaha $12 \%$, serta terdapatnya moment tertentu $32 \%$. Hal ini menunjukkan bahwa kerjasama yang dilakukan masih belum memerlihatkan win win solution, namun masih bersifat jangka pendek belum bersifat co-partnership atau kerjasama berkelanjutan.

\section{6) Kerjasama supplier}

Kerjasama dapat dilakukan dengan supplier bisnis, untuk menjaga kualitas layanan dan respon terhadap para wisatawan. Kerjasama sifatnya masih spontanitas yaitu $41 \%$ pada moment tertentu, $30 \%$ bila apabila terdapat events, dan merencanakan events sebesar 29\%. Dengan demikian kerjasama dengan supplier bisnis dibuat dalam bentuk layanan jangka panjang yang mampu memasok kebutuhan para wisatawan. Kerjasama dilakukan dengan saling menguntungkan dengan alasan harga menjadi lebih murah, memudahkan layanan, cepat merespons pelanggan, brand image serta lainnya. Kerjasama dilakukan saling menguntungkan apabila dapat memberikan produk yang berkualitas sesuai dengan kebutuhan dan keinginan dari kedua belah pihak sebesar 39\%, selanjutnya harga murah dengan kualitas produk yang baik sebesar 29\%, layanan yang memudahkan 
keberlangsungan selama kegiatan MICE berlangsung sebesar 25\%, sedangkan brand image bukan merupakan suatu hal yang penting karena Desa Ubud belum memiliki brand image yang tepat sehingga sebesar 5\%. Dengan demikian bahwa Desa Ubud sudah memberikan alasan yang benar dan memiliki jalur yang benar di dalam melakukan kerjasama dengan pemasok.

7) Ketersediaan transportasi (trave/s)

Transportasi yang terdapat di Desa Ubud merupakan sarana utama bagi turis untuk menjalankan aktivitas MICE untuk menuju ke beberapa tempat yang dituju terutama bagi wisatawan yang terlibat dalam program insentives dengan menyediakan transportasi berupa transport pribadi sebesar 77\%; angkutan wisata yang dimiliki oleh industry pariwisata seperti hotel dan perusahaan tour and travel sebesar $18 \%$ dan untuk grup disediakan bus medium yang dapat masuk ke Desa Ubud sebesar 5\%. Penggunaan dari transport pribadi dilakukan untuk memberikan kesempatan kepada masyarakat lokal di Desa Ubud untuk memeroleh pendapatan dari bidang pariwisata dengan memberikan jasa perjalanan wisata kepada wisatawan yang melakukan kegiatan MICE di Desa Ubud.

Penjemputan wisatawan MICE, mengantar spouse yang melakukan wisata dan mengantar ke Airport dengan menggunakan angkutan wisata yang dimiliki oleh hotel, tour and travel atau angkutan wisata yang dimiliki individu atau privat sebesar $47 \%$, selanjutnya menggunakan privat transport yang tidak memiliki ijin angkutan wisata dari dinas perhubungan sebesar 32\%, untuk mengunjungi lokasi yang relatif jauh dari tempat tinggal wisatawan atau melakukan studi banding, maka disediakan bus sebesar $14 \%$ dan penggunaan transportasi yang memudahkan wisatawan untuk bepergian sendirian dengan melakukan transport online dalam hal ini gojek sebesar 7\% karena dengan alasan lebih murah, serta waktu yang bebas. Dengan demikian ketersediaan transportasi yang bagus, nyaman dan memadai harus tersedia dengan mudah pada saat kegiatan berlangsung. Akses yang mudah, nyaman, aman dan 
ramah akan memberikan kepuasan dan akan mendatangkan loyalitas untuk datang kembali ke Desa Ubud.

\section{8) Layanan Kepuasan pelanggan}

Layanan pelanggan adalah hal utama bagi keberhasilan suatu bisnis. $\mathrm{Di}$ mana jawaban responden pada tangible $28 \%$; intangible dan emphaty sebesar $17 \%$; sedangkan assurance sebesar $26 \%$ dan responsiveness sebesar $29 \%$.

Kondisi bahwa layanan pelanggan tidak memuaskan terdapat pada kurangnya informasi layanan, infrastruktur, banyaknya kemacetan dijalan-jalan protokol di Desa Ubud. Untuk memerbaiki layanan harus segera diadakan adalah tempat dan papan informasi layanan mudah dilihat, perbaikan infrastruktur serta pelatihan untuk meningkatkan kualitas layanan front liner petugas pariwisata. Ini semua terkait erat dengan kepuasan pelanggan, atau para turis dan investor yang menanamkan modalnya di Desa Ubud.

\section{Faktor Keunggulan Bersaing}

Keunggulan bersaing sangat diperlukan dalam dunia bisnis. Keunggulan bersaing diperlukan analisis industri meliputi keberadaan wisatawan, investor, tempat wisata.

\section{a) Analisis industri}

Di dalam analysis industri untuk kemajuan pariwisata untuk menyongsong MICE diperlukan investor pariwisata sebesar $29 \%$, tempat wisata alternatif sebesar $28 \%$ dan destinasi dan tipe wisatawan yang baru untuk pasar MICE sebesar $24 \%$, wisatawan, tempat hiburan dan lainnya sebesar $14 \%$. Tujuan strategi bersaing untuk menemukan posisi Desa Ubud terhadap bidang-bidang yang menjadi fokus terhadap bisnis MICE, dan melakukan diversifikasi baik terhadap "produk" maupun "jasa" yang menjadi keluaran MICE.

b) Lingkungan bisnis eksternal.

Lingkungan eksternal adalah lingkungan yang diperlukan bagi para wisatawan agar kegiatan berpariwisata berjalan seperti diharapkan dan 
memberikan tingkat kepuasan maksimal. Keberadaan seperti tempat budaya $47 \%$; tempat ekonomi mencapai $8 \%$, tempat sosial mencapai $18 \%$, tempat olah raga $5 \%$, lainnya menyangkut tempat upacara dan ibadah (pura yang memiliki peran yang penting di Desa Ubud dan sekitarnya) sebesar 19\%. Kegiatan yang banyak dilakukan para wisatawan adalah menelusuri cagar budaya, tempat sejarah, kegiatan ekonomi atau shopping. Selain itu kegiatan wisatawan yang lain adalah berkaitan dengan budaya, aktivitas spiritual serta shopping.

\section{c) Situasi Pasar (Market situation)}

Pasar berkaitan dengan produk, tempat, harga, promosi serta lainnya. Desa Ubud sebagai destinasi MICE menekankan pada harga sebesar 29\% , produk $36 \%$, promosi sebesar $18 \%$, sedangkan tempat sebesar $17 \%$. Hal tersebut menunjukkan wisatawan melihat hasil karya di mana mereka berwisata, selanjutnya melihat berapa harganya, serta bagaimana promosinya.

d) Efektivitas sumber daya yang flexible

Sumberdaya di Desa Ubud perlu didayagunakan secara fleksibel. Kebutuhan efektivitas sumberdaya adalah alam $42,85 \%$, sumberdaya manusia $21,42 \%$, infrastruktur $14,29 \%$, dana, metode dan pasar mencapai $7,14 \%$. Selanjutnya sumber daya manusia dari berbagai lini perlu berperan maksimal atau diberdayakan untuk mendukung Ubud sebagai destinasi MICE, selanjutnya menggali pendanaannya, metodenya serta pasarnya. Kedepan untuk destinasi MICE adalah dibutuhkan data tentang informasi wisata sebesar $35,29 \%$, pengelolaan waktu secara tepat sebesar $29,41 \%$, moral sebesar $23,52 \%$ dan kepemimpinan sebesar $11,76 \%$. Kondisi ini menjelaskan bahwa informasi pariwisata menjadi sarana utama bagi para wisatawan sehingga perlu menyediakan tempat informasi secara cukup, dan paket wisata di kelola secara tepat waktu. 
e) Perbedaan Kompetensi

Perbedaan Desa Ubud dengan desa lainnya sangat menentukan masa depan Desa Ubud sebagai destinasi MICE. Yang membedakan dengan desa lainnya adalah wisata alam, tempat bersejarah, budaya, serta kuliner. Kompetensi yang dibutuhkan Desa Ubud untuk mewujudkan MICE adalah peningkatan layanan informasi, serta moral.

Kemampuan Desa Ubud mengidentifikasi ketersediaan sumberdaya dan daya dukungnya akan menciptakan keunggulan, baik dari sisi efisiensi, kualitas, innovasi, daya tanggapnya terhadap para wisatawan serta memberikan tingkat kepuasan bagi pendatang baru yang berinvestasi di Desa Ubud. Perbedaan dengan desa lain dengan penciptaan biaya yang rendah memungkinkan Desa Ubud menciptakan nilai (value creation) bagi para wisatawan maupun investor yang akhirnya mendapatkan keuntungan maksimal (higher profit). Jadi perbedaan kompetensi bukan terletak pada faktor tangiblenya namun terletak pada faktor intangible yang mampu membedakan dengan desa pariwisata yang lain.

Faktor Kunci Keberhasilan Kritis

Kompetensi Desa Ubud adalah tersedianya fasilitas sarana serta prasarana seperti hotel 41,66\%; ruang exhibition sebesar 33,33\%; ruang meetings sebesar $16,66 \%$, ruang conference masih $0 \%$. Hal ini menunjukkan ruang hotel sudah memenuhi ketersediaan, hal yang sangat urgent adalah ruang conference baik tingkat lokal, regional dan international. Demikian pula ruang untuk meeting dan tempat terbuka yang mampu menampung jumlah ratusan ribu orang ternyata belum tersedia secara signifikan. Berdasarkan data di buat analisis SWOT, dapat dilihat secara garis besar yang menjadi seperti tabel berikut ini. 
Tabel 5. SWOT Desa Ubud

PELUANG
- Banyak Festival
- Banyak Pameran
- Banyak Tempat Terbuka untuk events
- Banyak Tempat Belanja Souvenir Tersedia
- Banyak Daya Tarik Budaya Dan Sejarah
- Banyak Daya Tarik Religi
- Banyak Tempat Kuliner
- Letak Geografis yang berbeda
- Banyaknya tawaran kerjasama investor
- Events terjadi berulang ulang

- Banyak Festival

- Banyak Pameran

- Banyak Tempat Terbuka untuk events

- Banyak Tempat Belanja Souvenir Tersedia

- Banyak Daya Tarik Budaya Dan Sejarah

- Banyak Daya Tarik Religi

- Banyak Tempat Kuliner

- Letak Geografis yang berbeda

- Banyaknya tawaran kerjasama investor

- Events terjadi berulang ulang

\begin{tabular}{|c|c|}
\hline KE & KELEMAHAN \\
\hline 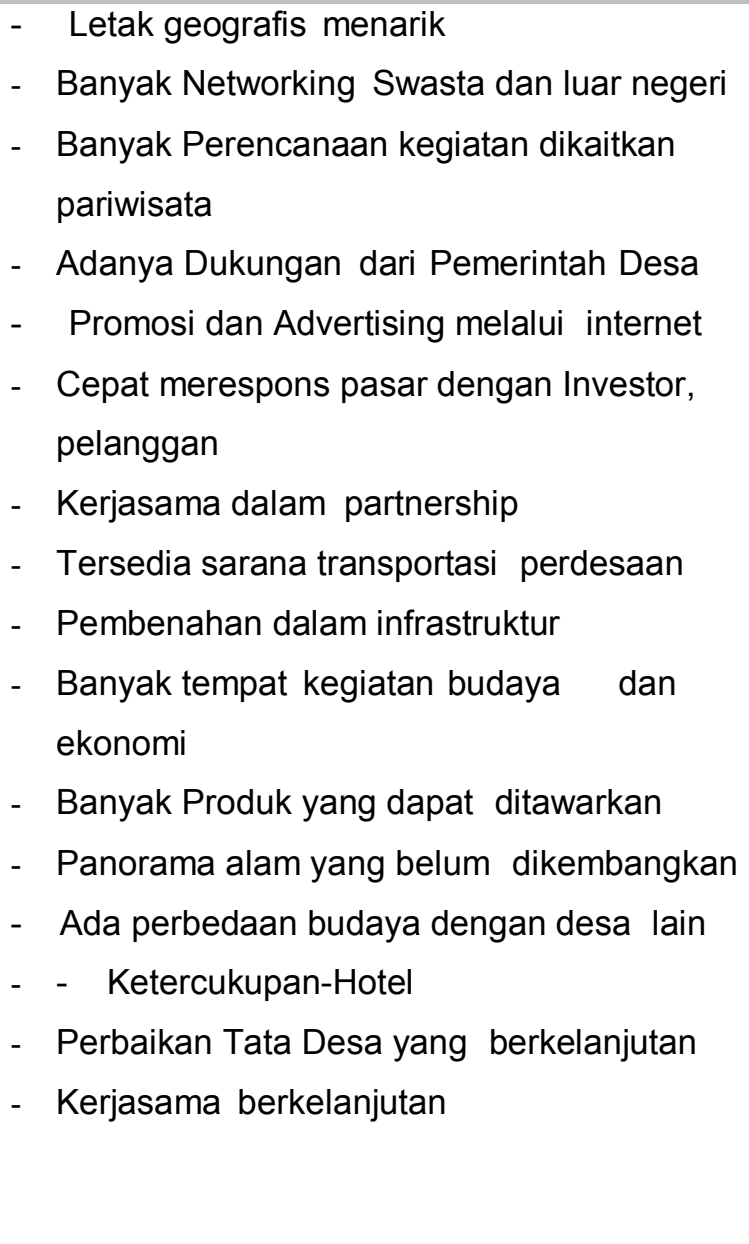 & $\begin{array}{l}\text { - Tempat Budaya belum tertata maksimal } \\
\text { - Tempat Pagelaran dan ekonomi kurang } \\
\text { Teratur } \\
\text { - Terdapat Events sama berulang-ulang } \\
\text { - Hotel Promosinya kurang terintegrasi } \\
\text { dengan wisata } \\
\text { - Wisata Alam belum tergarap secara } \\
\text { maksimal } \\
\text { - Event Kurang terpadu } \\
\text { - Wisata kuliner kurang tertata } \\
\text { - Event belum berdampak nyata bagi } \\
\text { kesejahteraan rakyat } \\
\text { - Terdapat TIC (tourism information } \\
\text { centre) tapi belum mampu bekerjasama } \\
\text { - Masyarakat desa masih banyak yang } \\
\text { belum sadar wisata } \\
\text { - - Masih berpikir untung rugi belum ber } \\
\text { Pikir benefit jangka panjang } \\
\text { - Tempat event belum dimaksimalkan } \\
\text { - Belum melibatkan Semua potensi yang } \\
\text { dimiliki Desa Ubud }\end{array}$ \\
\hline
\end{tabular}

Sumber: Hasil Penelitian 2017 
Analisis SWOT dilihat dari faktor internal ditujukan pada kekuatan (strenght) yaitu kebutuhan pelanggan yang bisa atau sudah dipenuhi.

Tabel 6. Matrix SWOT.

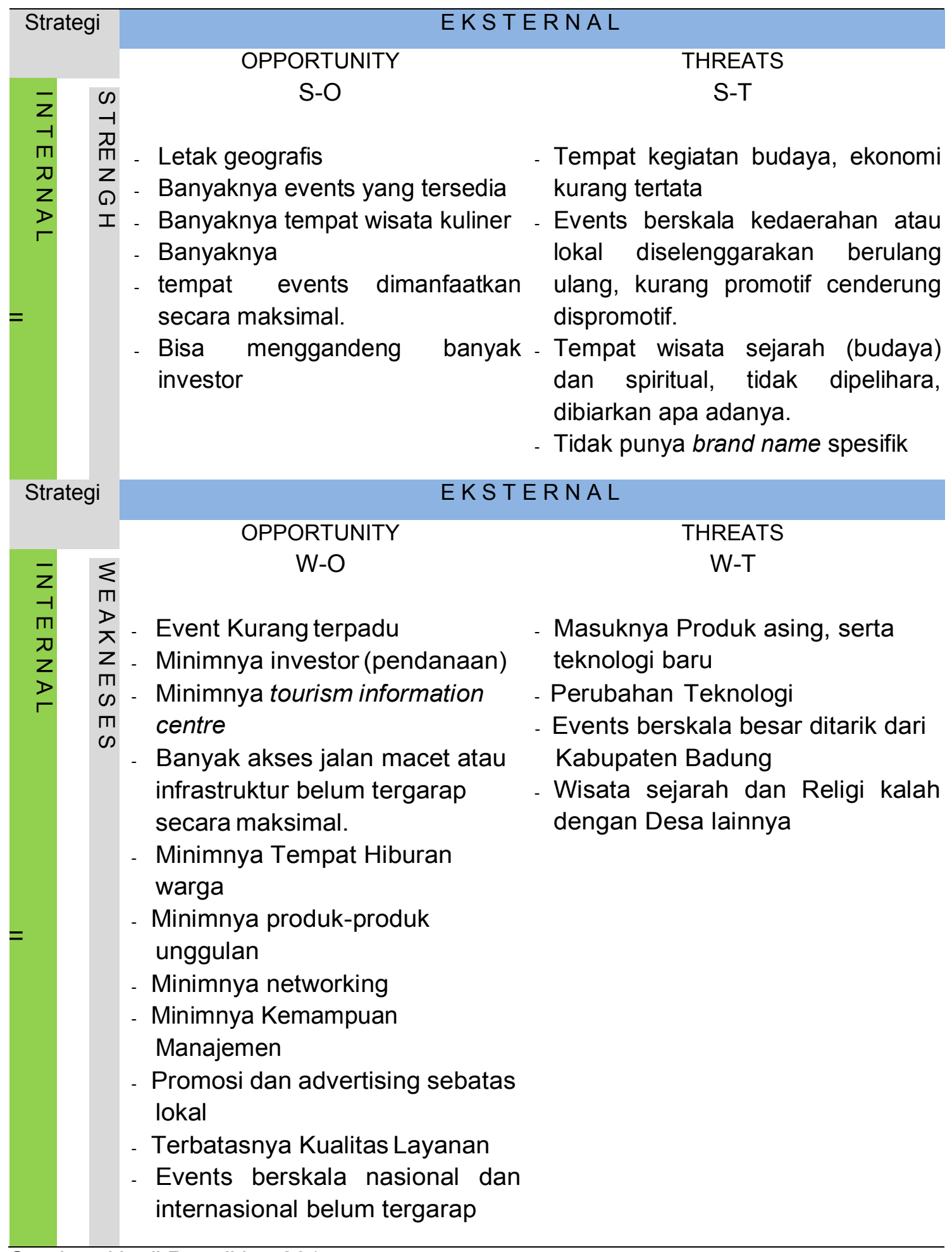

Sumber: Hasil Penelitian 2017 
Sedangkan kelemahan (weakness) dihubungkan dengan kebutuhan pelanggan yang perlu diminimalisir. Selain itu faktor eksternal ditunjukkan peluang (opportunity) yang bisa dikembangkan di Desa Ubud, dan ancaman (threats) yang diminimalkan. di dalam mengembangkan destinasi MICE. strategi yang dikembangkan apabila $\mathrm{S}>\mathrm{W}$ dan $\mathrm{O}>\mathrm{T}$ digunakan strategi perluasan (expansion) dan bila $\mathrm{S}<\mathrm{W}$ dan $\mathrm{O}<\mathrm{T}$ digunakan strategi konsolidasi (consolidation). Hasilnya dapat ditarik suatu kesimpulan bahwa di Desa Ubud masih dalam kategori $\mathrm{S}<\mathrm{W}$ dan $\mathrm{O} \geq \mathrm{T}$ dengan demikian masih harus dilakukan konsolidasi internal; namun melihat $\mathrm{O} \geq \mathrm{T}$ masih punya potensi yang bisa dilakukan pemasaran lebih lanjut.

\section{ANALISIS KONDISI INTERNAL DAN EKSTERNAL}

Berdasarkan hasil studi di lapangan masing-masing variabel nampak pada Tabel 7. Besarnya nilai variabel internal.

Tabel 7. Nilai Rata-Rata Variabel Internal

\begin{tabular}{|c|c|c|}
\hline No & Faktor-Faktor Kunci & Nilai \\
\hline 1 & Lokasi Penyelenggaran Pameran & 0.3 \\
\hline 2 & Tempat Penginapan (Hotel) & 0.4 \\
\hline 3 & Transportasi & 0.3 \\
\hline 4 & Kompetensi Penyelenggara Pameran (competency) & 0.1 \\
\hline 5 & Organisasi Penyelenggara & 0.3 \\
\hline 6 & Tuntutan kebutuhan konvensi (Place of Interest) & 0.1 \\
\hline 7 & Paket wisata dalam konvensi (Post Convention Tour) & 0.3 \\
\hline 8 & Organisasi Konvensi & 0 \\
\hline \multicolumn{2}{|r|}{ Jumlah } & 1.8 \\
\hline \multicolumn{3}{|c|}{$\begin{array}{l}\text { Analisis variabel eksternal meliputi globalisasi, potensi wisata, struktur industri } \\
\text { ekonomi, teknologi, dan pemerintah dapat dilihat sebagai berikut } \\
\text { Tabel 8. Nilai variabel Eksternal }\end{array}$} \\
\hline Tabel ह & Faktor-Faktor Kunci & Nilai \\
\hline & Globalisasi & 0.1 \\
\hline & Potensi Wisata & 0.6 \\
\hline & Struktur Industri & 0.4 \\
\hline & Ekonomi & 0.3 \\
\hline & Teknologi & 0.1 \\
\hline & Pemerintah & 0.5 \\
\hline & $\mathrm{Jumlah}$ & 1.1 \\
\hline
\end{tabular}


Berdasarkan Tabel 7. dan 8, nilai variabel internal sebesar 1,8 (kondisi peluang tinggi ) dan variabel eksternal 1,1 (kondisi peluang tinggi). Dengan mendasarkan pada kedua nilai variabel tersebut maka posisi Desa Ubud sebagai Destinasi MICE dapat dilihat pada gambar di bawah.

Strategi

Berdasarkan positioning Desa Ubud sebagai Destinasi MICE terletak pada kondisi variabel internal sebesar 1,8 (kondisi peluang tinggi) dan variabel eksternal 1.1 (kondisi peluang tinggi) maka pilihan strategi nampak pada gambar 2.

Tabel 9. Kondisi Eksternal dan Internal

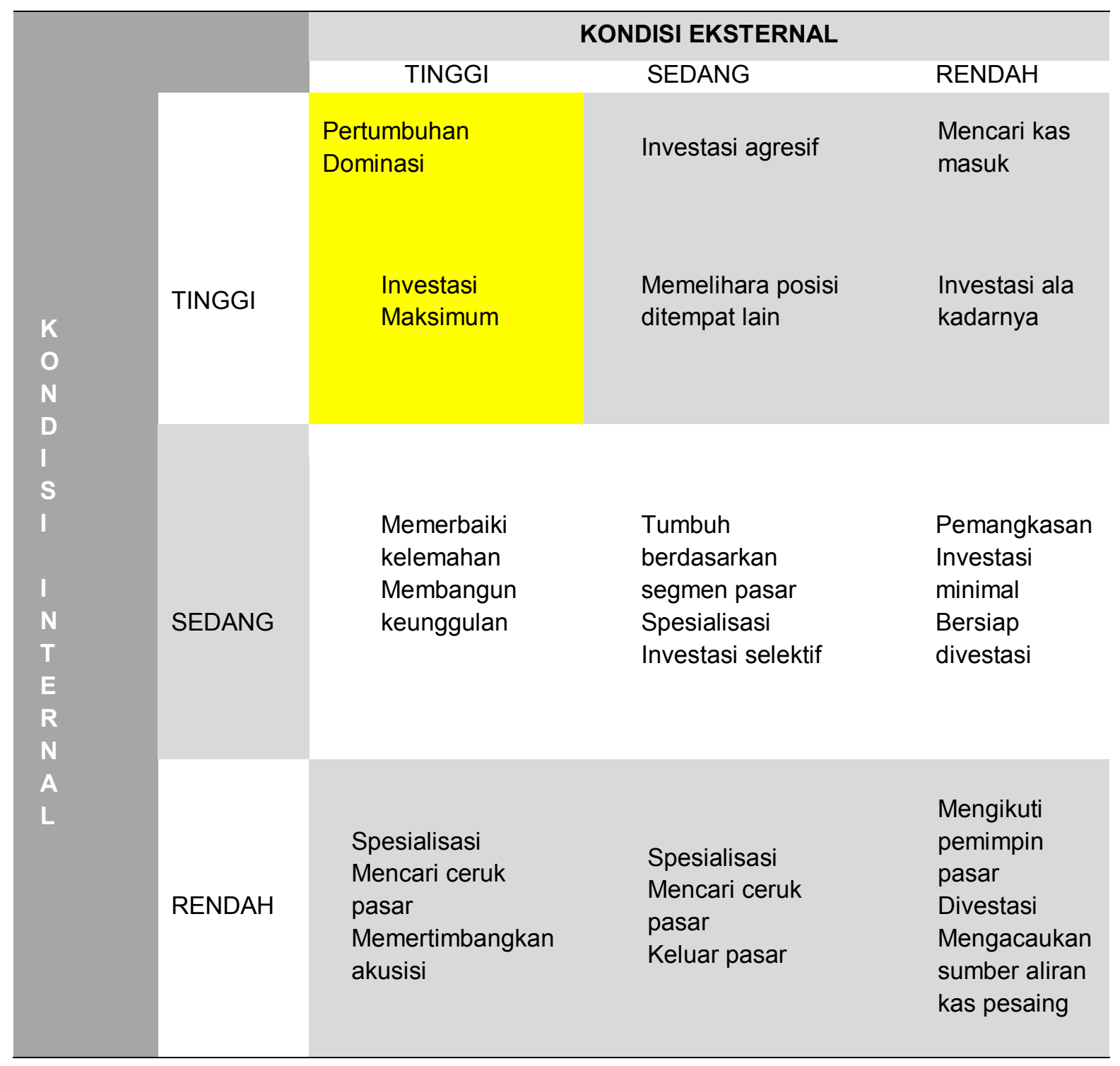


Berdasarkan S W O T di atas dapat di buat suatu matrik strategi pemasaran Desa Ubud sebagai Destinasi MICE menuju percepatan dapat dilihat pada Tabel 5. Matrik Sebagai Berikut.

Tabel 10. Matriks Strategi Pemasaran Desa Ubud sebagai Destinasi MICE

\begin{tabular}{|c|c|c|c|}
\hline Strategi & Program & Action Plan & Keterangan \\
\hline \multirow[t]{3}{*}{ Pertumbuhan } & $\begin{array}{l}\text { Membuat event yang lebih } \\
\text { bervariasi dan unik }\end{array}$ & $\begin{array}{l}\text { Melibatkan stakeholder } \\
\text { pariwisata dalam } \\
\text { pembuatan program }\end{array}$ & $\begin{array}{l}\text { Masih } \\
\text { Kurang }\end{array}$ \\
\hline & $\begin{array}{l}\text { Meningkatkan Event Skala } \\
\text { Nasional dan International }\end{array}$ & $\begin{array}{l}\text { Kerjasama dengan } \\
\text { penyelenggara kegiatan } \\
\text { skala nasional dan } \\
\text { internasional }\end{array}$ & Koordinasi \\
\hline & $\begin{array}{l}\text { Menata tempat kegiatan } \\
\text { budaya, ekonomi dan } \\
\text { spiritual }\end{array}$ & $\begin{array}{l}\text { Mengintegrasikan dalam } \\
\text { satu paket wisata }\end{array}$ & Belum Ada \\
\hline \multirow[t]{2}{*}{ Dominasi } & $\begin{array}{l}\text { Menguatkan branding } \\
\text { sebagai Desa Berbudaya }\end{array}$ & $\begin{array}{l}\text { Mempromosikan potensi } \\
\text { budaya, ekonomi, spiritual } \\
\text { dan kuliner }\end{array}$ & Koordinasi \\
\hline & $\begin{array}{l}\text { Meningkatkan jaringan } \\
\text { kerjasama dengan } \\
\text { stakeholder dan TIC }\end{array}$ & $\begin{array}{l}\text { Kerjasama dengan } \\
\text { pemangku pariwisata baik } \\
\text { dalam maupun luar negeri }\end{array}$ & Koordinasi \\
\hline \multirow[t]{2}{*}{$\begin{array}{l}\text { Investasi } \\
\text { Maksimum }\end{array}$} & $\begin{array}{l}\text { Menggandeng investor } \\
\text { yang peduli dan mau } \\
\text { menjaga budaya adat Bali }\end{array}$ & $\begin{array}{l}\text { Kerjasama dengan } \\
\text { investor yang berkualitas } \\
\text { baik dalam maupun luar } \\
\text { negeri }\end{array}$ & $\begin{array}{l}\text { Masih } \\
\text { Kurang }\end{array}$ \\
\hline & $\begin{array}{l}\text { Peningkatan Alokasi } \\
\text { anggaran untuk } \\
\text { infrastruktur dan Kegiatan } \\
\text { Wisata MICE }\end{array}$ & $\begin{array}{l}\text { Pengusulan melalui APBD } \\
\text { maupun melalui donasi } \\
\text { dan bantuan dari pihak } \\
\text { swasta }\end{array}$ & Koordinasi \\
\hline
\end{tabular}

Dari hasil analisis SWOT disimpulkan bahwa Desa Ubud masih berada $\mathrm{S}>\mathrm{W}$ dan $\mathrm{O} \geq \mathrm{T}$ dengan demikian memerlukan konsolidasi internal; namun melihat $\mathrm{O} \geq \mathrm{T}$ memiliki potensi yang dapat dikembangan lebih lanjut.

\section{SIMPULAN DAN SARAN}

Simpulan yang dapat diberikan adalah sebagai berikut.

Grand strategi yang dipergunakan adalah sebagai berikut a. Pertumbuhan b. Dominasi dan c. Investasi Maksimum, secara rinci dapat di lihat pada Tabel 10 yaitu Matrik Strategi. Kelemahan mendasar terletak pada 
belum tersedianya ruang konvensi yang memadai di Desa Ubud sehingga menyebabkan sulit berkembangnya wisata MICE, demikian pula dengan kurang koordinasi antar tourism information center yang masih memiliki kepentingan dan berjalan sendiri-sendiri, belum memiliki branding, masih memerlukan investor yang peduli dengan budaya adat Bali untuk pemasaran di bidang pariwisata dan bisnis, promosi belum maksimal, banyak akses jalan macet atau infrastruktur belum tergarap secara maksimal, kerjasama berkelanjutan dengan private sector serta investor dalam dan luar negeri, tujuannya agar lebih banyak dana yang masuk untuk menciptakan akselerasi pembangunan.

Faktor Keunggulan Bersaing Desa Ubud sebagai Destinasi MICE dapat dilakukan melalui pemasaran sektor pendukung Destinasi MICE seperti a. investasi, b. perizinan, c. perindustrian, d. perhubungan, e. perdagangan dan jasa, f. kesehatan dan keamanan, g. dan kesenian atau budaya. Di bidang investasi fokus pada penyediaan fasilitas penyelenggaraan Destinasi MICE. dengan mengangkat budaya-budaya adat Bali yang begitu kuat di Desa Ubud. Peluang investasi dari luar negeri di bangun melalui regulasi maupun insentif, perlu dimanfaatkan secara maksimal.

Faktor Kunci Keberhasilan Kritis, pelaksanaan Destinasi MICE tergantung ruangan hotel, ruang meeting; ruang incentive; ruang conference; dan ruang exhibition dan sarana penunjang. selain itu tuntutan sumber daya manusia profesional untuk mengelola dan mengorganisir konvensi tersebut. terselenggaranya destinasi MICE disesuaikan tuntutan global perspective tourisme, tergantung pada komponen owner, supplier, profesional convention organizer, profesional exhibition organizer dan lain lain.

Berikut adalah beberapa saran yang harus diperhatikan.

Grand strategi sebagai Destinasi MICE, yaitu memerbaiki kelemahan dan membangun keunggulan Desa Ubud, perlu ditindak lanjuti, dalam program dan action plan.

Faktor Keunggulan bersaing dapat diwujudkan melalui perbaikan penunjang pemasaran sektor pendukung wisata MICE seperti a. investasi, b. perizinan, c. perindustrian, d. perhubungan, e. perdagangan dan jasa, f. kesehatan dan keamanan, g. dan kesenian atau budaya. 
Faktor kritis keberhasilan memerlukan fasilitas gedung atau ruang konvensi yang layak untuk tempat penyelenggaraan MICE.

Untuk mewujudkan Ubud setara diwujudkan melalui event event secara terintegrasi, sejogjanya beskala nasional dan internasional dan memberikan effect bagi kesejahteraan masyarakat desa Ubud, serta dipromosikan mendunia.

\section{DAFTAR PUSTAKA}

Cooper, Chris, Jhon Flecher, David Gilbert and StephenWainhill. 1993. Tourism Principle and Practice. London: Pitman Publishing.

http: //venuemagz.com/September-2012/seminar-wisata-spiritual-go-to-balibefore-i-die.html diunggah pada tanggal 24 November 2015.

Kotler, P. 2002. Manajemen Pemasaran. Jilid I Edisi Bahasa Indonesia. Jakarta: Pearson Education Asia Ptc. Ltd. Dan PT Prenhallindo.

Kotler, P. Bowen, J. Makens, J. 2002. Pemasaran Perhotelan dan Kepariwisataan. Edisi Bahasa Indonesia, edisi kedua. Jakarta: Pearson Education Asia Pte. Ltd. Dan Pt Prenhallindo.

Kotler, P. dan Susanto,A.B. 1999. Manajemen Pemasaran di Indonesia, Analisis, Perencanaan, Implementasi dan Pengendalian. Edisi Pertama. Jakarta: Salemba Empat.

Pitana I Gde, Gayatri Putu G. 2005. Sosiologi Pariwisata. Yogyakarta: Andi Offset.

Pitana I Gde, Surya Diarta. 2009. Pengantar IImu Pariwisata. Yogyakarta: CV. Andi Offset.

Plog, S, 2001. Why Destination Areas Rice and Fall in Popularity" (An Update of Cornell Quarterly Clasic), Cornell Hotel and Restaurant Administration Quarterly (13-24)

Pearce, Douglas1990, Tourism Development, Longman Scientific \& Technical, Harlow-London

Pendit S. Nyoman. 1999. Wisata Konvensi, Potensi Gede Bisnis Besar. Jakarta: PT. Gramedia Pustaka

Robinson Tarigan 2005, Perencanaan Pembangunan Wilayah Pt Bumi Aksara, Jakarta.

Seaton, A.V. dan M.M. Bennett. 1996, The Marketing of Tourism Product: Concepts, Issues, and Cases. International Thomson Business Press, London. 
Sucherly. 2003. Strategi Pemasaran Jasa dalam Meningkatkan Keunggulan Bersaing. Dalam Strategi Baru Manajemen Pemasaran. Editor Usmara, A. Jogjakarta: Amara Book.

Timoty, D.J. 2002."Sacred joureys: religious heritage and tourism," Tourism Recreation Reseach 27 (2): 3-5 Issues in Global Touris.

Timoty, J Dalen and Daniel H. Olsen. 2006. Tourism, Religion \& Spiritual Journeys. Abingdon: Routledge. 